
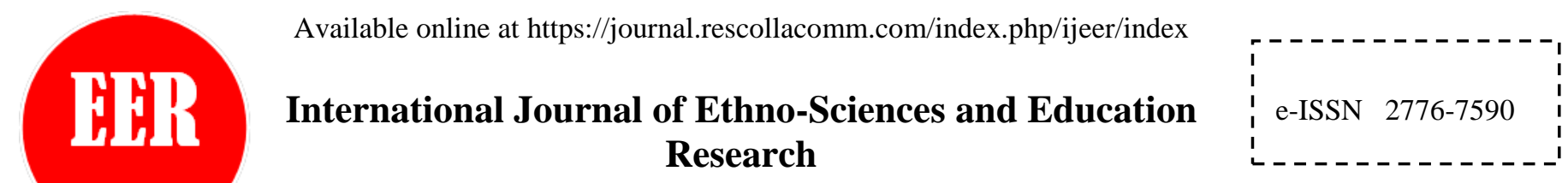

Vol. 1, No. 2, pp. 36-39, 2021

\title{
Several Methods to Teach Reading to Early Childhood
}

\author{
Vera Sri Wahyuni* \\ Research Collaborations Community, Bandung, Indonesia \\ *Corresponding author email: acenx.bts@gmail.com
}

\begin{abstract}
One of the challenges now faced by the parents of young children, especially at the early childhood level of education is to teach reading. This paper aims to find out some more effective ways to teach reading to the children. The method discussed in this paper include: using children's songs and books, using game card, through guessing game, using variety of study applications, and the parent's patience. The results of the study show that in order to teach reading to early childhood, the parent or teacher must be able to choose a method that suits the child's situation, abilities and interests. Thus, it will able to increase children's ability and interest in reading and avoid boredom.
\end{abstract}

Keywords: early childhood education, teaching, reading, children's ability, interest

\section{Introduction}

Reading is an important activity because it can support children's language and communication skills. In addition, reading can also train a child's brain creative thinking ability. Although there may be some challenges in teaching children to read, parents still need to build children's interest so that they love reading. Teaching reading to early childhood is one of the challenges parents must face, especially during the Early Childhood Education (ECE) level. Moreover, during the Covid-19 pandemic, the learning activities moves from school to home and the closure of reading and writing tutoring institutions made parents need to provide time to teach children to learn reading at home. Therefore, how to properly teach children to read and what if children are still reluctant to learn reading are the question that parents must be able to find how to answer it. Teaching children how to read at early childhood should be done through fun activities. Thus, the learning to read activities can increase sensitivity and motivate children to continue learning because the ability to read can be a starting point for children to get to know their world.

Several studies related to teach reading to early childhood such as Herlina (2019) that undertook a study of controversy of early childhood children learn to read which often become contentious. This study aims to answer teachers' doubts about reading activities for early childhood. Early Childhood Education is the basis for the formation of various children's abilities. One activity that need to be instilled from an early age is reading. Learning to read given to early childhood is not a topic of debate anymore but what must be considered is learning to read is given in an interesting, creative, fun and without coercion Based on the results of this study, it is concluded that in the era of education 4.0, that prioritizes technology, teachers are expected to be able to use technology as a learning medium to teach pre-reading. Darnis (2018), conducted a study with the aim of looking at an effective learning model for developing literacy and numeracy in early childhood. Many teachers feel trapped and go awry in the process of learning to read, write and count because the existing education system does not allow early childhood to learn to read, write and count at school. When the teacher starts at school, the parents can also help the learning process at home. The ability to read, write, and count is not an ambition that must be fulfilled but rather to foster children's interest in reading, writing and arithmetic itself.

Based on the description above, this paper intends to conduct a study on how to teach reading to early childhood. The aim is to find out some more effective ways to teach reading to early childhood. Through this study, it is hoped that parents can choose and apply methods of teaching reading to early childhood that are interesting and fun. 


\section{Material and Methods}

The Materials used in this study are articles from several scientific works published in scientific journals, books, and articles published in electronic media through the website.

The methods of this study on how to teach reading to young children include: using children's songs and books, using card games, through a guessing game, using diverse learning applications and books, and parent's patience.

\section{1) Using children's songs and books}

The initial steps can be in done to teach children to read is to encourage children to listen his favorite songs and rhymes. Apart from making it a fun activity, this can also enrich children's vocabulary. When the vocabulary of the child increases, encourage him to recognize it in the order of letters. Learning to read can also be done by inviting children to read a lot of story books in simple words, while recognizing letters and words.

\section{2) Card games}

Make a game card containing simple words related to the equipment or toys in the house. Train the children to stick the card on the object according to what is written on the card.

\section{3) Through guessing games}

Encourage children to remember things they have learned through guessing games that can create a fun learning atmosphere. Try to get the child to guess the sound of the words the parents write on a piece of colored paper.

\section{4) Using of various learning applications}

Learning to read should be a fun process to keep children motivated to learn. Therefore, there is nothing wrong with parents using various types of reading applications or learning books; therefore, the learning process is more focused and enjoyable.

\section{5) Parents' patience}

It should be understood that every child has their own rhythm and speed in understanding something, including in learning to read. Thus, the patience of parents is also the main key so the children remain motivated to continue learning. In addition, parents can also choose and instill good learning habits; therefore, children always study regularly and do not get bored easily.

\section{Results and Discussion}

Using children's songs and books. In general, music affects the development of children's intellectual and could make the children good at socializing. It similar when teaching early aged (1-6 years old) children; children will be happy and eager to learn when invited to sing. However, it is very unfortunate that children in this day and age would rather sing the adult songs. Although it is rare to find children's themed song nowadays, this is not a reason to not introducing regional or national songs to the children. Start to introduce appropriate songs for their age because it will give positive impact. In general, songs will be able to affect the right and left-brain function. The benefits of songs for the right brain will be more complete if we ask children to sing while drawing, coloring, identify the picture and other interesting activities. In addition, the function of left brain can be seen when the children can remember the remember the lyrics, counting, answering and asking questions and other activities (https://balistung.com ).

Card games. Games are a variety of activities that actually designed with the intention to increase certain children ability on the learning experience. Game is a tool for children to explore their world from which the children knowing something and able to do something. Alphabet game card is a number of cards as a tool to help the children learning to read by way of noticing and remembering the shape of the letters and the accompanied pictures on the card. Alphabet cards contains pictures, letters, signs or symbols which increase or guiding children to associate the letter with the picture or symbols. The alphabet card which referred here is the self-made card with rectangle shape of white paper. On one side is the letter and on the other side is the image with written information about the image. Through the card game is a learning method for early childhood children to recognize letters. Children learn to recognize letters by looking at the letter symbol and picture on the card. As a result, based on the explanation, it can be confirmed that the card game method is a learning activity using card as a tool which contain letter symbols, pictures and written information about the picture. The purpose is to improve the ability to know or get to know and understand the letters alphabetically (https://text -en.123dok.com). 
Guessing games. Children is the age at which they really like to play with friends in the same age. Playing with peers is one of those moments that cannot be forgotten. In the spare time, children love to play riddle. They play in order to entertain during their spare time. Early childhood funny riddles should not involve heavy themes. Children at early age are thinking about light entertainment for them to be able to laugh with parents or peers. Riddles for early childhood can also hone their level of creativity. Although, usually these riddles are also entertainment in nature, children will practice thinking critically with their peers. Parents or teachers cannot prevent children if they really want to play with their peers; however, supervise their actions would also be necessary. The goal is that they can be comfortable playing with their peers in an environment that they feel is suitable for playing and communicating (https://www.merdeka.com).

Using various learning applications. Electronic media has many advantages that can be used to support children's reading and learning activities. One of media is Reading material software for early childhood is in the form of screenshots or often called page slide. For children, reading material is also presented in very attractive form such as the illustrations that make the child imagine when reading the reading material. Additionally, sometimes reading materials are also supplied sound effects which also attracted the enthusiasm of a child. Features in the form of games can be used as an approach for children to increase their interest in reading. Games that emphasize the conscientious children will stimulate their concentration power. Likewise, games that invite users to move quickly, of course, will indirectly increase the agility of the child. With all the advantages of electronic media as a learning medium, of course the role of parents is needed in supervision; therefore, the progress of children is directed and the electronic media utilizes to build children's interest in learning. Children need to be constantly motivated so their learning interest is consistent and persistent. Motivating does not mean instilling a paradigm that learning is the most important compared to doing other activities. Forcing children to always learn is not the best step for a child's growing period (https://bimba-aiueo.com).

Parent's patience. Each parent must have wanted their children able to read quickly. However, skill is not solely be formed if it is not supported by parent's attitude, patience and example. That is why if we want the children grow well and skilled in reading, parents also need to be patient in teaching children to read. In addition to patience, verbal discipline verbal from the parents can also very damaging for children interest to read. When the parents often reprimand by shouting or angry, the child tends to loos interest in reading and would have behavior problems because the children emotionally disturbed. Even a child could have low self-esteem, easily angry, rude, and have high level depression. Parents who yell and get angry are losing patience or not able to control their emotions. It is sure to give bad impact on the children and even reading can be frightening for children (https://www.haibunda.com).

\section{Conclussion}

In this paper, a study has been carried out on several ways of teaching early childhood to read. Based on the results of the study, it can be concluded that to teach reading to early childhood can be done by using: the children's songs and book, card game, through guessing game, using various learning application and parent's patience. Parent or teacher must be able to choose the method according to the situation, abilities and interests of the children. This is so the parent or teacher is able to develop abilities and interests of children to read and avoid boredom.

\section{References}

Herlina, E. S. (2019). Membaca Permulaan Untuk Anak Usia Dini Dalam Era Pendidikan 4.0. Jurnal Pionir LPPM Universitas Asahan, 5(4), 332-342.

Brewer, J. A. (2007). Introduction Early Childhood Education Preschool through Primary Grades, Sixth Edition. Boston: Allynan Bacon.

Darnis, S. (2018). Aplikasi Montessori Dalam Pembelajaran Membaca, Menulis dan Berhitung Tingkat Permulaan Bagi Anak Usia Dini. Jurnal Caksana - Pendidikan Anak Usia Dini, 1(1), 1-10.

Edwards, C. M. (2014). Maternal Literacy Practices and Toddler's Emergent Literacy Skills. Journal of Early Childhood Literacy, 14, 53-79.

Kleemans, T., Peeters, M., Segers, E., \& Verhoeven, L. (2012).Child and Home Predictors of Early Numeracy Skills in Kindergarten. Early Childhood Research Quarterly, 27, 471-477.

Niklas, F., Cohrssen, C., \& Tayler, C. (2016). The Sooner, the Better: Early Reading to Children. SAGE Open, 1-11.

Niklas, F., \& Schneider, W. (2013). Home Literacy Environment and the Beginning of Reading and Writing. Contemporary Educational Psychology, 38, 40-50. 
Phillips, B. M., \& Lonigan, C. J. (2009). Variations in the Home Literacy Environment of Preschool Children: A Cluster Analytic Approach. Scientific Studies of Reading, 13, 146-174.

https://balistung.com/manfaat-lagu-untuk-anak-usia-dini/

https://www.merdeka.com/jatim/40-tebak-tebakan-lucu-anak-tk-kocak-dan-cocok-jadi-hiburan-kln.html

https://bimba-aiueo.com/memanfaatkan-gadget-untuk-membangun-minat-belajar-anak/

https://www.haibunda.com/parenting/20181129112856-62-29474/3-cara-agar-orang-tua-lebih-sabar-hadapi-anak

https://text-id.123dok.com/document/8yd83896q-pengertian-metode-permainan-kartu-huruf-langkah-langkah-permainan-kartuhuruf.html 